\title{
Pengaruh Status Sosial Ekonomi Orang Tua dan Lingkungan Belajar terhadap Prestasi Belajar Bahasa Indonesia
}

\author{
Jaka Sunarya \\ Fakultas Pascasarjana, Universitas Indraprasta PGRI \\ Jalan Nangka No. 58 C/TB. Simatupang, Tanjung Barat, Jakarta Selatan 12530 \\ jakasunarya94@gmail.com
}

\begin{abstract}
The purpose of the study is to know the effect of the parents' social-economic status and the learning environment toward the learning achievement of Indonesian language. The method of the research is a descriptive survey using some samples from a number of population. Some questionnaires are for data collection. The population is all grade eight (8) of the Islamic Public Junior High School in North Jakarta with a total population of 598 students. The result of the research shows that; 1 ). There is a collectively significant effect of the parents' economical social status and the learning environment toward the learning achievement of Indonesian language of the Islamic Public Junior high school students of North Jakarta. The significant effect was shown by the score of Sig. $=0,000$ $<0,05 \mathrm{andF} 0=50,900$. Both variables, the parents' social-economic status, and the learning environment had given a contribution of $64,1 \%$ to the learning achievement of Indonesian language. 2). There is a significant effect off of the parents' social-economical status toward the learning achievement of Indonesian language of the Islamic Public Junior high school students of North Jakarta. The significant effect was shown by the score of Sig. $=0,000<0,05$ and $t 0=4,632$. The parents' social-economical status variable had given a contribution to the learning achievement of Indonesian language of 26,15\%.3). There is a significant effect of the learning environment toward the learning achievement of Indonesian language of the Islamic Public Junior high school students of North Jakarta. The significant effect was shown by the score of Sig. $=0,000<0,05$ and $\mathrm{t} 0=6,050$. This variable had given a contribution to the learning achievement of Indonesian language of $37,9 \%$.
\end{abstract}

Keywords: parents' social-economic status, learning environment, and learning achievement.

\begin{abstract}
Abstrak
Tujuan penelitian adalah untuk mengetahui Pengaruh Status social-ekonomi orang tua dan lingkungan belajar terhadap prestasi belajar bahasa Indonesia. Metode penelitian yang digunakan adalah metode survei deskriptif. Populasi dalam penelitian ini adalah seluruh siswa kelas VIII MTs Negeri di Jakarta Utara dengan jumlah populasi sebanyak 598 dari siswa kelas VIII MTs Negeri 5 dan MTs Negeri 39 Jakarta Utara. Hasil penelitian ini menunjukkan bahwa: 1) Terdapat pengaruh yang signifikan status social-ekonomi orang tua dan lingkungan belajar secara bersama-sama terhadap prestasi belajar bahasa Indonesia siswa MTs Negeri Jakarta Utara. Hal ini dibuktikan dengan perolehan nilai Sig. $0,000<0,05$ dan $F_{\text {hitung }}=50,900$. Secara bersama-sama variabel status social-ekonomi orang tua dan lingkungan belajar memberikan kontribusi sebesar $64,1 \%$ kepada variable prestasi belajar bahasa Indonesia. 2) Terdapat pengaruh yang signifikan status socialekonomi orang tua terhadap prestasi belajar bahasa Indonesia siswa MTs Negeri Jakarta Utara. Hal ini dibuktikan dengan perolehan nilai Sig. $0,000<0,05$ dan $t_{\text {hitung }}=4,632$. Kontribusi yang diberikan variabel status social-ekonomi orang tua kepada variabel prestasi belajar bahasa Indonesia sebesar 26,15\%.3). Terdapat pengaruh yang signifikan lingkungan belajar terhadap prestasi belajar bahasa Indonesia siswa MTs Negeri Jakarta utara. Hal ini dibuktikan dengan perolehan nilai Sig.0,000 < 0,05 dan $t_{\text {hitung }}=6,050$. Kontribuai yang diberikan varialbel lingkunagn belajar kepada variabel prestasi belajar bahasa Indonesia sebesar $37,9 \%$
\end{abstract}

Kata Kunci: status sosial-ekonomi orang tua, lingkungan belajar, prestasi belajar bahasa Indonesia 


\section{PENDAHULUAN}

Orang tua dengan pola pikir modern akan menempatkan pendidikan sebagai prioritas utama terhadap anak sebagai wujud menuaikan tanggung jawab. Para orang tua akan memilih layanan-layanan pendidikan yang memiliki kualitas yang lebih baik sebagai tempat yang dipercaya mampu memberikan pelayanan pendidikan yang terbaik bagi anaknya. Hal ini tentu berisiko terhadap pembiayaanpembiayaan pendidikan anak yang jumlahnya tidak sedikit. Namun, hal tersebut tidak menjadi persoalan mengingat hasil yang akan didapatkan sesuai dengan harapan.

Sejalan dengan pemikiran orang tua, layanan-layanan pendidikan pun mulai bersaing dalam meningkatkan kapasitasnya guna menjawab permintaan dari orang tua. Fenomena tersebut tentu akan membuat perbedaan hasil belajar yang diperoleh anak berdasarkan pemilihan layanan pendidikan (sekolah) antara orang tua yang memiliki kemampuan dalam memfasilitasi pendidikan anaknya pada sekolahsekolah yang bermutu dengan sikap orang tua yang terkesan masa bodo dengan pendidikan anak sehingga anak tidak mendapatkan pendidikan yang maksimal dari sebuah layanan pendidikan sekolah.

Status sosial ekonomi merupakan keadaan seseorang yang dilihat dari segi sosial ekonomi. Status sosial ekonomi kemungkinan besar adalah tolak ukur sebuah keluarga untuk menentukan gaya hidup. Pada masing-masing satuan pendidikan, keberhasilan belajar siswa ditentukan oleh berbagai komponen pendidikan seperti kemampuan guru, kurikulum, lingkungan, sarana dan prasarana, teknik pengajaran, materi ajar, serta keadaan siswa itu sendiri.

Komponen yang sangat penting di samping kemampuan guru adalah faktor lingkungan. Lingkungan memegang peranan penting dalam meningkatkan hasil belajar. Lingkungan selalu melekat dengan kehidupan manusia. Lingkungan dan manusia dapat saling memengaruhi. Hal itu juga berlaku dalam proses belajarmengajar. Lingkungan belajar punya perang penting dalam keberhasilan pembelajaran.

Lingkungan mencakup material, stimulus di dalam maupun di luar individu sebagai sumber belajar, baik yang bersifat fisiologis, maupun sosiokultural (Dalyono, 2007). Menurut (Tarigan, 2008) bahwa "transformasi informasi menjadi bagian dari proses perkembangan anak". Apabila penyampaian materi tersebut disajikan dalam lingkungan yang kondusif, maka siswa akan dengan semangat mengikuti kegiatan pembelajaran dengan serius.

Berdasarkan pada pemikiran di atas, status sosial ekonomi orang tua dan lingkungan belajar siswa dapat berpengaruh terhadap prestasi belajar bahasa Indonesia siswa yang pada akhirnya mengarah pada keberhasilan pencapaian tujuan pendidikan baik secara mikro, maupun secara makro. Prestasi adalah pencapaian siswa pada sebuah program (Syah, 2017). Sejalan dengan itu, "Prestasi belajar adalah rumusan terakhir yang dapat diberikan oleh guru mengenai prestasi belajar selama masa tertentu" (Suryabrata, 2007). Prestasi belajar dikatakan sempurna apabila memenuhi tiga aspek, yakni kognitif, afektif, dan psikomotor.

Menurut (Sardiman, 2005), "Belajar adalah berubah" dalam hal ini yang dimakud berubah adalah usaha untuk mengubah tingkah laku. Dengan demikian,

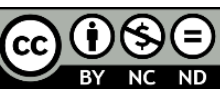

Creative Commons Attribution-NonCommercial-NoDerivatives 4.0 International License 
belajar itu sebagai rangkaian kegiatan jiwa raga, psiko-fisik untuk menuju perkembanan pribadi manusia seutuhnya. Syah menyatakan "Pada dasarnya belajar merupakan titipan perubahan seluruh tingkah laku individu yang relatif menetap sebagai hasil pengalaman yang melibatkan proses kognitif, afektif dan pskiomotorik yang terjadi dengan siswa" (Syah, 2017). Menurut (Slameto, 2003) "Belajar ialah suatu proses perubahan tingkah laku secara keselurahan.

Pendapat lain dikemukakan oleh (Purwanto, 2002) "Belajar merupakan perubahan perilaku akibat dari latihan atau pengalaman yang menyangkut kepribadian baik secara fisik, maupun psikis". Hal ini dapat dilihat dari sejauh mana perubahan yang telah terjadi melalui kegiatan belajar-mengajar.

Pengajar harus mengetahui bagaimana siswa sudah mengerti bahan ajar yang telah diajarkan. Pengukuran prestasi belajar tersebut dapat menggunakan suatu alat untuk mengevaluasi yaitu melalui tes yang digunakan untuk menilai hasil belajar dan hasil mengajar. Untuk mengukur prestasi belajar diperlukan evaluasi dan penilaian. Tes tertulis atau lisan yang mencakup materi yang sudah diajarkan di waktu tertentu dapat menjadi bahan evaluasi dan penilaian. Dalam penelitian ini penulis menggunakan dokumentasi nilai rapor yang dibuktikan dengan angkaangka hasil dari proses belajt-mengajar dalam kurun waktu satu semester.

Dalam proses belajar-mengajar tidak lepas dari sarana dan prasarana. Untuk memenuhi sarana dan kelengkapan tersebut diperlukan dana. Masalah ketersediaan dana untuk menunjang pendidikan peserta didik yang baik berkaitan dengan kondisi ekonomi orang tua. Kondisi ekonomi adalah status atau kedudukan yang merekat pada seseorang yang dapat dilihat dari pola kehidupan sehari-hari melalui ciri-ciri tertentu yang dinamakan status simbol. Rendahnya tingkat pendapatan keluarga akan berdampak minimnya kemampuan membeli sebuah keluarga (Suhardjo, 2003).

Berdasarkan pembahasan di atas, disimpulkan bahwa status sosial ekonomi dapat dilihat dari pola kehidupan sehari-hari. Hal-hal tersebut dapat memengaruhi prestasi yang akan diperoleh atau dicapai oleh anak-anak mereka. Lingkungan adalah sesuatu yang ada di sekeliling manusia yang memengaruhi tingkah laku. Slameto mengemukakan bahwa "lingkungan belajar siswa yang memengaruhi hasil belajar siswa terdiri dari keluarga, sekolah, dan masyarakat" (Slameto, 2003).

Lingkungan belajar siswa menyangkut aspek fisik dan aspek nonfisik. Aspek fisik sekolah meliputi lokasi sekolah, kondisi bangunan, kebersihan lingkungan, keluarganya dan masyarakat sekitarnya serta teman-teman belajar atau bermainnya. Aspek nonfisik sekolah meliputi sikap dan perlakuan guru, hubungan guru dan siswa, hubungan siswa dengan masyarakat sekitarnya, dan juga hubungan siswa dengan teman-temannya, karakteristik tata tertib sekolah, serta cara pelaksanaan tata tertib sekolah. Lingkungan pertama yaitu lingkungan keluarga. Keluarga merupakan pondasi pertama prasekolah yang dikenal oleh seorang anak. Lingkungan keluarga adalah segenap rangsangan interaksi dan kondisi dalam hubungannya dengan perilaku ataupun orang yang berada di sekitarnya. Lingkungan belajar yang kedua adalah lingkungan sekolah. Selain itu, lingkungan masyarakat juga salah satu faktor yang besar pengaruhnya terhadap hasil belajar siswa. Lingkungan masyarakat berpengaruh terhadap perkembangan pribadi anak dan pergaulannya. Apabila anak-anak rajin belajar, maka akan terdorong untuk 


\section{Diskursus: Jurnal Pendidikan Bahasa Indonesia}

Vol. 1, No. 2, Agustus 2018, pp. 146-153

p-ISSN: 2615-4935

e-ISSN: 2615-4943

rajin belajar pula. Sebaliknya, jika yang lainnya malas, akan berpengaruh negatif pula.

\section{METODE}

"Metode penelitian yang digunakan adalah survei deskriptif dengan menggunakan kuesioner" (Riduwan, 2009). "Kuesioner berisi pertanyaan yang digunakan untuk mencari informasi dari responden terkait hal-hal yang ia ketahui" (Arikunto, 2010). Data dari hasil kuesioner selanjutnya dianalisis secara deskriptif. Tujuan penelitian deskriptif ini untuk membuat gambaran secara sistematik, faktual, dan akurat.

\section{HASIL DAN PEMBAHASAN}

\section{Hasil}

Proses pengolahan data dibantu dengan program SPSS versi 2.0. Berikut merupakan data yang dihasilkan.

Tabel 1. Hasil Perhitungan Pengujian Koefisien Korelasi Ganda Variabel $X_{1}$ dan $X_{2}$ terhadap $Y$

\begin{tabular}{|l|c|c|c|c|}
\hline Model & R & R Square & $\begin{array}{c}\text { Adjusted R } \\
\text { Square }\end{array}$ & $\begin{array}{c}\text { Std. Error of } \\
\text { the Estimate }\end{array}$ \\
\hline 1 & $.801^{\text {a }}$ & .641 & .628 & 7.476 \\
\hline
\end{tabular}
a. Predictors: (Constant), Lingkungan belajar, Status sosial
ekonomi orang tua

Tabel 2. Hasil Perhitungan Pengujian Signifikansi Koefisien Regresi Variabel $X_{1}$ dan $X_{2}$ terhadap $Y$

\begin{tabular}{|c|c|c|c|c|c|c|}
\hline \multicolumn{7}{|c|}{ ANOVA $^{a}$} \\
\hline Model & & $\begin{array}{l}\text { Sum of } \\
\text { Squares }\end{array}$ & df & Mean Square & $\mathrm{F}$ & Sig. \\
\hline 1 & Regression & 5689.861 & 2 & 2844.931 & 50.900 & $.000^{6}$ \\
\hline & Residual & 3185.872 & 57 & 55.892 & & \\
\hline & Total & 8875.733 & 59 & & & \\
\hline
\end{tabular}

a. Dependent Variable: Prestasi belajar bhs Indonesia

b. Predictors: (Constant), Lingkungan belajar, Status sosial ekonomi orang tua

Coefficients $^{\mathrm{a}}$

\begin{tabular}{|c|c|c|c|c|c|c|}
\hline \multirow{2}{*}{\multicolumn{2}{|c|}{ Model }} & \multicolumn{2}{|c|}{ Unstandardized Coefficients } & \multirow{2}{*}{$\begin{array}{c}\text { Standardized } \\
\text { Coefficients } \\
\text { Beta }\end{array}$} & \multirow[b]{2}{*}{$t$} & \multirow[b]{2}{*}{ Sig. } \\
\hline & & B & Std. Error & & & \\
\hline \multirow[t]{3}{*}{1} & (Constant) & -13.078 & 8.977 & & -1.457 & .151 \\
\hline & $\begin{array}{l}\text { Status sosial ekonomi } \\
\text { orang tua }\end{array}$ & .512 & .110 & .408 & 4.632 & .000 \\
\hline & Lingkungan belajar & .412 & .068 & .533 & 6.050 & .000 \\
\hline
\end{tabular}

a. Dependent Variable: Prestasi belajar bhs Indonesia

Pengaruh status sosial ekonomi orang tua $\left(\mathrm{X}_{\mathrm{I}}\right)$ dan Lingkungan belajar $\left(\mathrm{X}_{2}\right)$ secara bersama-sama terhadap Prestasi belajar bahasa Indonesia (Y).

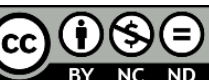


Hipotesis yang diuji:

Ho: $\beta \mathrm{y}_{1}=\beta \mathrm{y}_{2}=0$

$\mathrm{H}_{1}: \beta \mathrm{y}_{1} \neq 0, \beta \mathrm{y}_{2}=0$

Artinya:

Ho: tidak terdapat pengaruh status sosial ekonomi orang tua dan lingkungan belajar secara bersama-sama terhadap prestasi belajar bahasa Indonesia.

$\mathrm{H}_{1}$ : terdapat pengaruh status sosial ekonomi orang tua dan lingkungan belajar secara bersama-sama terhadap prestasi belajar bahasa Indonesia.

Dari tabel di atas dapat dinyatakan bahwa adanya pengaruh yang signifikan status sosial ekonomi orang tua dan lingkungan belajar secara bersama-sama terhadap prestasi belajar bahasa Indonesia. Hal itu dibuktikan dengan nilai Sig.0,000<0,05 dan $F_{\text {hitung }}=$ 50,900. Sementara itu, persamaan garis regresi ganda dapat dinyatakan dengan $\hat{Y}=13.078+0,512 \mathrm{XI}+0,412 \mathrm{X} 2$. Hal ini memiliki pengertian bahwa kenaikan nilai variabel status sosial ekonomi orang tua dan lingkungan belajar memberikan kontribusi sebesar 0,512 oleh $\mathrm{X}_{1}$ dan 0,412 oleh $\mathrm{X}_{2}$ kepada variabel prestasi belajar bahasa Indonesia. Data tersebut juga dapat menjelaskan bahwa secara bersama-sama variabel status sosial ekonomi orang tua dan lingkungan belajar memberikan kontribusi sebesar $64,1 \%$ kepada variabel prestasi belajar bahasa Indonesia.

\section{Pengaruh status sosial ekonomi orang tua $\left(\mathrm{X}_{1}\right)$ terhadap prestasi belajar bahasa Indonesia (Y)}

Hipotesis yang diuji:

Ho: $\beta \mathrm{y} 1=0$

$\mathrm{H} 1: \beta \mathrm{y} 1 \neq 0$

Artinya:

$\mathrm{H}_{0}$ : tidak terdapat pengaruh status sosial ekonomi orang tua terhadap prestasi belajar bahasa Indonesia

$\mathrm{H}_{1}$ : terdapat pengaruh status sosial ekonomi orang tua terhadap prestasi belajar bahasa Indonesia

Dari tabel di atas menunjukkan bahwa terdapat pengaruh yang signifikan pengaruh status sosial ekonomi orang tua terhadap prestasi belajar bahasa Indonesia. Hal itu karena nilai Sig. 0,000<0,05 dan thitung $=4,632$. Adapun kontribusi variabel status sosial ekonomi orang tua kepada prestasi belajar bahasa Indonesia dapat dinyatakan dengan rumus:

$$
\begin{aligned}
& \mathrm{KD}=\text { Nilai } \beta X 1 Y X \text { Nilai Korelasi Pasialnya }\left(r_{\mathrm{X} 1 \mathrm{Y}}\right) \mathrm{X} 100 \% \\
& \mathrm{KD}=0,408 \mathrm{X} 0,641 \times 100 \%=26,15 \%
\end{aligned}
$$


Dari hasil perhitungan di atas dapat dinyatakan bahwa kontribusi status sosial ekonomi orang tua dalam meningkatkan prestasi belajar bahasa Indonesia sebesar $26,15 \%$.

\section{Pengaruh lingkungan belajar $\left(\mathrm{X}_{2}\right)$ terhadap prestasi belajar bahasa Indonesia} (Y)

Hipotesis yang diuji:

Ho: $\beta \mathrm{y} 1=0$

$\mathrm{H}_{1}: \beta_{y l} \neq 0$

Artinya:

Ho: tidak terdapat pengaruh lingkungan belajar terhadap prestasi belajar bahasa Indonesia

$\mathrm{H}_{1}$ : terdapat pengaruh lingkungan belajar terhadap prestasi belajar bahasa Indonesia.

Dari tabel tersebut dapat dinyatakan bahwa terdapat pengaruh yang signifikan lingkungan belajar terhadap prestasi belajar bahasa Indonesia. Hal ini dibuktikan dengan perolehan nilai Sig. $0,000<0,05$ dan $t_{\text {hitung }}=6,050$. Adapun kontribusi variabel lingkungan belajar kepada prestasi belajar bahasa Indonesia dinyatakan dengan rumus:

$\mathrm{KD}=$ Nilai $\beta_{X 2 Y} \mathrm{X}$ Nilai Korelasi Pasialnya $\left(r_{x 2 y}\right) \mathrm{X} 100 \%$

$\mathrm{KD}=0,533 \mathrm{X} 0,711 \mathrm{X} 100 \%=37,9 \%$

Dari hasil perhitungan di atas dapat dinyatakan bahwa kontribusi lingkungan belajar dalam meningkatkan prestasi belajar bahasa Indonesia sebesar $37,9 \%$.

\section{Pembahasan}

Pengaruh status sosial ekonomi orang tua $\left(\mathrm{X}_{1}\right)$ dan lingkungan belajar $\left(\mathrm{X}_{2}\right)$ secara bersama-sama terhadap prestasi belajar bahasa Indonesia (Y)

Dapat disimpulkan bahwa ada pengaruh status sosial ekonomi orang tua dan lingkungan belajar secara bersama-sama terhadap prestasi belajar bahasa Indonesia. Hal ini mengandung arti bahwa status sosial ekonomi orang tua dan lingkungan belajar telah memberikan pengaruh yang signifikan terhadap prestasi belajar bahasa Indonesia siswa MTs Negeri Jakarta Utara.

Menurut sintesis teori yang ada, siswa memerlukan berbagai dukungan baik bersifat materi maupun nonmateri. Faktor di sini adalah status sosial ekonomi orang tua. Tingkat status sosial ekonomi orang tua merupakan faktor penting yang dapat memengaruhi prestasi belajar siswa. Faktor - faktor yang menentukan tingkat status sosial ekonomi. Berdasarkan kodrat-Nya manusia dilahirkan memiliki kedudukan yang sama dan sederajat, tetapi tentunya kedudukan dan peran warga dalam suatu masyarakat adalah suatu kenyataan.

Ada beberapa faktor penentu tinggi-rendahnya tingkat status sosial ekonomi orang tua, seperti, jenis pekerjaan, tingkat pendidikan, tingkat pendapatan, 
pemilikan kekayaan, kondisi lingkungan tempat tinggal, dan partisipasi dalam aktivitas kelompok dari komunitasnya. Dengan demikian, jika tingkat status sosial ekonominya baik, maka diasumsikan bahwa prestasi belajar anaknya akan baik juga.

Faktor lainnya adalah lingkungan belajar yang mendukung terjadinya proses belajar-mengajar yang tepat guna. Berlangsungnya kegiatan belajar yang mendapat pengaruh dari luar terhadap keberlangsungan kegiatan tersebut merupakan definisi dari lingkungan belajar. Lingkungan belajar yang positif memiliki pengaruh dalam proses pembelajaran.

\section{Pengaruh status sosial orang tua $\left(\mathrm{X}_{1}\right)$ terhadap prestasi belajar bahasa} Indonesia (Y).

Dari hasil penelitian dan teori yang ada dapat disimpulkan bahwa status sosial ekonomi orang tua telah memberikan pengaruh positif terhadap prestasi belajar bahasa Indonesia siswa MTs Negeri Jakarta Utara. Artinya, adanya status sosial ekonomi yang baik telah memberikan pengaruh positif terhadap prestasi belajar bahasa Indonesia. Menurut sintesis teori yang ada, status sosial ekonomi orang tua adalah suatu tata kehidupan dan penghidupan sosial, material, maupun spiritual yang diliputi rasa keselamatan, kesusilaan dan ketenteraman lahir dan batin yang memungkinkan setiap warga negara untuk mengadakan usaha-usaha pemenuhan kebutuhan jasmani, rohani, dan sosial yang sebaik-baiknya bagi diri, keluarga serta masyarakat.

Semakin tinggi tingkat status sosial ekonomi orang tua, maka semakin tinggi kemampuan oran tua tersebut dalam men-suport anak-anaknya mengikuti pendidikan, baik bersifat formal, maupun nonformal. Siswa yang kebutuhan materinya terpenuhi cenderung akan merasa senang dan semangat dalam mengikuti pembelajaran di sekolah termasuk pelajaran bahasa Indonesia. Dengan demikian, prestasi belajar bahasa Indonesia juga tercapai.

\section{Pengaruh Lingkungan belajar $\left(\mathbf{X}_{1}\right)$ terhadap prestasi belajar bahasa Indonesia (Y).}

Berdasarkan hasil penelitian di atas dapat disimpulkan bahwa lingkungan belajar telah memberikan pengaruh positif terhadap prestasi belajar bahasa Indonseia siswa MTs Negeri Jakarta Utara. Hal ini mengandung arti bahwa lingkungan belajar memberikan pengaruh yang cukup signifikan terhadap prestasi belajar bahasa Indonesia siswa MTs Negeri Jakarta Utara. Hal ini menunjukkan bahwa lingkungan belajar sangat berpengaruh dalam menciptakan suasana belajar menyenangkan. Lingkungan belajar dapat meningkatkan keaktifan belajar. Oleh sebab itu, lingkungan belajar perlu ditata dengan semestinya.

\section{SIMPULAN}

Dari pembahasan dan hasil penelitian dapat disimpulkan sebagai berikut:

1. Terdapat pengaruh yang signifikan status sosial ekonomi orang tua dan lingkungan belajar terhadap prestasi belajar bahasa Indonsia siswa MTs Negeri Jakarta Utara. Hal ini dibuktikan dengan perolehan nilai Sig. 0,000 $<0,05$ dan 
$F_{\text {hitung }}=50,900$. Secara bersama-sama variabel status sosial ekonomi orang tua dan lingkungan belajar memberikan kontribusi sebesar 64,1\% kepada variable prestasi belajar bahasa Indonesia.

2. Terdapat pengaruh yang signifikan status sosial ekonomi orang tua terhadap prestasi belajar bahasa Indonesia siswa MTs Negeri Jakarta Utara. Hal ini dibuktikan dengan perolehan nilai Sig.0,000< 0,05 dan $t_{\text {hitung }}=4,632$. Kontribusi status sosial ekonomi orang tua dalam meningkatkan prestasi belajar bahasa Indonesia sebesar 26,15.

3. Terdapat pengaruh yang signifikan lingkungan belajar terhadap prestasi belajar bahasa Indonesia siswa MTs Negeri Jakarta Utara. Hal ini dibuktikan dengan perolehan nilai Sig. $0,000<0,05$ dan $t_{\text {hitung }}=6,050$. Kontribusi lingkungan belajar dalam meningkatkan prestasi belajar bahasa Indonesia sebesar 37,9\%

\section{DAFTAR PUSTAKA}

Arikunto, S. (2010). Prosedur penelitian suatu pendekatan praktik. Jakarta: Rineka Cipta.

Dalyono, M. (2007). Psikologi pendidikan. Jakarta: Rineka Cipta.

Purwanto, N. (2002). Psikologi pendidikan. Bandung: PT Remaja Rosda Karya.

Riduwan. (2009). Belajar mudah penelitian untuk guru-karyawan dan peneliti pemula. Bandung: Alfabeta.

Sardiman, A. M. (2005). Interaksi dan motivasi dalam belajar mengajar. Jakarta: Raja Grafindo Persada.

Slameto. (2003). Belajar dan faktor-faktor yang mempengaruhinya. Jakarta: Rineka Cipta.

Suhardjo, C. M. K. (2003). Berbagi cara pendidikan gizi. Jakarta: Bumi Aksara.

Suryabrata, S. (2007). Psikologi pendidikan (Suatu pengajaran secara operasional. Yogyakarta: Rake Press.

Syah, M. (2017). Psikologi pendidikan dengan pendekatan baru. Bandung: PT Remaja Rosda Karya.

Tarigan, H. G. (2008). Menulis sebagai suatu keterampilan berbahasa. Bandung: Angkasa. 